\title{
THE FOREIGN POLICY OF THE UNITED STATES: LEADING POWER?
}

\begin{abstract}
The United States, with its historical background of exceptionalism, rose to power in the twentieth century and has maintained it until today. If it were not for the state's economic power and its strong institutions within the three branches of government, the U.S. would not be now a dominant global power and a regional hegemonic leader. Thus, even when faced with the lack of leadership, the state is able to retain its dominance in the international arena. Supported with a short review of U.S. history, this article presents the state's (in) activism in global politics during Obama's presidency.
\end{abstract}

\section{Key words}

Obama, U.S. history, Syria, Russia, China, Israel, U.S. institutions.

\section{Introduction}

Much has been discussed about the validity of the argument that the United States (U.S.) is an exceptional nation that continues to be the hegemonic power due to its economy, its industry, its armed forces and power projection. And much of this discussion tends to focus on the figure of its current President, Barack Obama.

* School of Global Studies, Anáhuac University, México, e-mail: jessica.dealba@anahuac.mx 
Obama came to office in 2009, after winning the election over his adversary John McCain, of the Republican Party. During his campaign and in his inaugural speech, he talked about the need to change America's role in the world, by leading from behind - as stated by one of his advisors (Lizza, 2011). The main issue was to show a standpoint different from the former president George W. Bush's view of America's foreign policy.

President Obama was determined to reverse some of the ongoing actions, for example by closing the Guantanamo Bay facilities and by withdrawing troops from Afghanistan and Iraq. In lieu of that, his administration planned a "forward-deployed diplomacy" in the Asia-Pacific Region, which in turn left some European allies disappointed, and aggravated again the relationship with the one-time foe, Russia, which would have long-term effects on that region of the world.

Apparently President Obama perceives the world differently than some of the other big players do. He seemingly uses idealist and ultraliberal approach towards the realist world where some regions are being confronted with fundamentalist threats and conflicts - a situation not unlike the period after WWI, in which the general (erroneous) belief was that everyone in the world wanted peace.

All those issues lead to the question as to the viability of the notion of the American Century. After World War II, the United States emerged as a leader of the Western world and reshaped the international order. Nevertheless, the significant problems in U.S. economy and in its political system, together with the perceived lack of leadership, raises a question as to its decline.

There is enough evidence showing that the U.S. still remains the leading economy in the world, with technological advances, innovative and major industry; the state demonstrates its power and influence around the world; has the largest number of immigrants coming from all continents; it is the leader of the free world and the chief advocate of democracy. There is historical evidence that even with unexceptional presidents, but with its foundation of strong institutions, the country will continue to be the dominant power.

This article briefly analyses the different stages of isolationism and activism of the United States in global politics providing a short review of U.S. history. The focus is on Obama's foreign policy, which seems to avoid dealing with the crucial global issues. The last part offers some insights into the strength of American institutions and people as the U.S.' main source of power. 


\section{The United States and its rise to power}

The origins of the United States date back to the Thirteen Colonies and to 1607, when the first settlement was founded in Jamestown, Virginia. Throughout the seventeenth century the east coast of the continent was settled by a very diverse population of European origin which initially lived in isolated colonies until the perceived benefits of cooperation and tolerance overcame adversity. On July 4, 1776, the representatives of the Thirteen Colonies signed the Declaration of Independence and formed the United States, the first independent nation on the continent. A constitution was drafted to create a central government that would be given certain defined and limited powers, the states retaining the rest. The federal government with a president of the Republic, two legislative chambers, and a federal judiciary was based on the principles of the French Enlightenment.

At the time of the Civil War, most Americans had no great interest in foreign policy; their concerns were national and local. Either way, the young country started extending its influence through the acquisition of several small islands in the Pacific (Howland and Baker in 1857 and the Midway Islands in 1867), the purchase of Alaska from Russia in 1867, and the establishment of a naval station at Pago Pago (Samoa) in 1878, although the most important acquisition in the Pacific was the Hawaiian Islands (Cliffsnotes, 2014).

Despite this, the United States was dedicated to grow and thrive in certain isolation until in 1898 it decided to support the independence of Cuba, sparking a fight with Spain, which resulted in the U.S. acquiring Cuba, Puerto Rico, the Philippines and Guam (US Department of State, n.d.).

The necessity for expansion came as a response to the instability back when the colonies were founded. As J. Newell comments, the colonies controlled their own respective economies, but they were vulnerable to attacks of foreign powers. The U.S. envisioned its future as one where it would become both a commercial and military power by itself, without being economically constrained by Europe. America's nationalist sentiments, coupled with its desire to expand, contributed to the spreading of the doctrine of "manifest destiny", which would assist America on its endeavor to become a continental superpower (Newell, 2014, pp. 134-144) even if the manifest destiny had negative consequences for some countries, in particular Mexico.

By then, the United States had almost all the attributes of power: it was ahead or near almost every other country in terms of population, territory, economic resources and military potential, as well as its strategic location between two oceans. When President William McKinley sent a delegation to negotiate the 
Treaty of Paris in 1898, he declared they could not 'be unmindful design without any desire on our part or the war has brought us new duties and Responsibilities Which We must meet and Becomes discharge as a great nation on Whose growth and career from the Beginning the Ruler of Nations has plainly written the high command and pledge of civilization' (U.S. Department of State, n.d.).

But the United States, even being the largest economy at the end of the century, was not regarded as a major player in the international arena, until Presidents Theodore Roosevelt and Woodrow Wilson directed that economic power into military resources (Nye, 2015). During World War I, the United States was favored for several reasons: its economy was not subject to the negative consequences of the war. On the contrary, the country profited from the sale of products to be supplied to the Entente. Rapid industrialization was shown by the modification of the rules of foreign trade: in 1919, U.S. exports exceeded imports by more than three billion dollars, that is, almost half of total exports. By then, the export of manufactured products had surpassed that of agricultural products. However, by 1920 the general deterioration of economic conditions in the country was evident. The main world powers were recovering from the war, which meant a slowdown for the American economy and ultimately recession, high unemployment, bankruptcies and falling wages. After the Great Depression of 1928, Franklin D. Roosevelt won the 1932 elections and promised a New Deal for the American people. A series of measures related to banking, unemployment, agricultural policy and enterprise reform were taken (Folsom \& Folsom, 2010).

In 1939, the country as a whole was not ready for a new war and clearly uninterested in getting involved in non-American issues though F. D. Roosevelt was eager to intervene and the United States was waging an undeclared sea war with Germany in support of the United Kingdom. However, the Japanese attack on Pearl Harbor base precipitated the U.S. joining World War II. The war economy created new jobs and brought economic prosperity, coupled with advances in science and technology, especially in military development as the U.S. helped defeat the Axis powers.

President Harry Truman urged the Congress to enact the ideas of his predecessor to help the economy recover. However, the Congress voted for application of different measures (Folsom \& Folsom, 2010), yet at the end of the decade, the economy was in better health.

With a strengthened economy and by then full participation in international politics, the United States faced the Soviet Union during the Cold War, which transformed into a global conflict. From the end of the World War II to 1991, 
the balance of power on the globe was bipolar, with both superpowers having disproportionate shares of power resources, spheres of influence and alliances, and engaging in a nuclear arms race. That bipolarity ended with the fall of the Berlin Wall in 1989 and the collapse of the Soviet Union in 1991, leaving the U.S. as the only world superpower (Waltz, 2000, pp. 5-41): the American navy was equal in size to the next 17 navies combined, the U.S. forces had air superiority, and the military budget of the state was half of the global total; the U.S. also took the lead in space and cyber space (Nye, 2015).

\section{The Post-Cold War era}

According to Friedman, there were three elements that defined the post-Cold War world. The first was the power of the United States. The second was the rise of China as the center of global industrial growth, based on low wages. The third was the resurgence of Europe as a massive and integrated economic power. Nevertheless, between 1989 and 2001 the United States was deeply conflicted, as it was before, about its role in the world (Friedman, 2013).

As A. Etzioni (2004) describes, the U.S. oscillated between neo-isolationism and neo-interventionism, depending on whether it was concerned about issues like oil or human suffering. However, the 9/11 attacks greatly diminished that ambivalence as the United States committed itself to promoting the world order, using its superpower status and resources: 'Today, Washington's main message to the world seems to be, "Take dictation"' (Hirsch, 2004, p. 96). That global demonstration of power has led many to view the United States as an "American empire", as asserted by many authors, such as Michael Hardt, Antonio Negri, Andrew J. Bacevich, or Robert N. Bellah.

The National Security Strategy of the Bush administration for 2002 showed the United States' stance. Madeleine Albright referred to a passage in the document:

Given the goals of rogue states and terrorists, the United States can no longer solely rely on a reactive posture as we have in the past. The inability to deter a potential attacker, the immediacy of today's threats, and the magnitude of potential harm that could be caused by our adversaries' choice of weapons, do not permit that option. We cannot let our enemies strike first (Albright, 2003, p. 18).

Thus the attack on Afghanistan was to punish the radical regime of the Taliban and their support for number-one terrorist Osama bin Laden. Then the war with Iraq was started by George W. Bush, as a preemptive war strategy. A simplistic view of some analysts is that the invasion aimed to get control of Iraqi oil. An 
additional reason was the threat of weapons of mass destruction (WMD) and a rogue dictator. Less obvious was the fact that the United States was playing a broader strategy of demonstrating power in an area rife with conflicts. Even if it was never clear whether the WMD were a real threat for the United States, the broad strategy was not entirely mistaken - the mistake was the imposed peace followed by politically driven abandonment and withdrawal. The first person to blame was Bush for leaving a civilian, Paul Bremer, in charge when an armed forces' general would have been a better choice. Nevertheless, the second to blame would be President Obama, for withdrawing all forces from a country still experiencing a sectarian war, making all the lives lost and all resources spent a waste.

Nevertheless, after the Iraq and Afghanistan interventions, and after the serious economic crisis of 2008-09, the United States remains the dominant political, economic and military power; the European Union is engaged in internal debates about where they are going as a heterogeneous entity whose countries suffer high unemployment and economic recession. Meanwhile China has structural weaknesses that will be difficult to overcome quickly. Both Europe and China perceived the world in the post-Cold War period in a similar way, believing that geopolitical and even domestic policy issues could be ignored as they had entered a period of permanent prosperity. In the words of G. Friedman:

[t]here is a paradox in all of this. While the United States has committed many errors, the fragmentation of Europe and the weakening of China mean the United States emerges more powerful, since power is relative. It was said that the post-Cold War world was America's time of dominance. I would argue that it was the preface of U.S. dominance. Its two great counterbalances are losing their ability to counter U.S. power because they mistakenly believed that real power was economic power. The United States had combined power - economic, political and military - and that allowed it to maintain its overall power when economic power faltered. A fragmented Europe has no chance at balancing the United States. And while China is reaching for military power, it will take many years to produce the kind of power that is global, and it can do so only if its economy allows it to. The United States defeated the Soviet Union in the Cold War because of its balanced power. Europe and China defeated themselves because they placed all their chips on economics. And now we enter the new era (Friedman, 2013).

But even if China replaces the United States as the first global economy, it does not mean the end of the so called American Century (Lind, 2014) if we consider the three dimensions of power: economic, military and soft power; moreover, 
the U.S. is able to use its resources to affect the global balance of power in a way unavailable to others (Nye, 2015).

Certainly, American policy is not a result of the actions of the the president himself. It involves the functioning of the whole government, its institutions and its people, even if thr head of state does nothing to improve or affect a given situation.

\section{Is Obama going to destroy America?}

As the White House web page, the power of the Executive Branch is vested in the President of the United States, who also acts as the head of state and Commanderin-Chief of the armed forces, and is responsible for implementing and enforcing the laws as written by the Congress (The White House, 2015).

As such, there are claims that President Obama and the Senate Democrats of his first term and a half of the second opened a new chapter in the "social democratization" or "domestication" of America. The change was driven by hard times and soft ends. The financial calamity and ideological preference, affirmed twice by more than half of the electorate, have converged to reduce the U.S. strategic profile (Joffe, 2013). This can be illustrated by several examples:

Syria. The internal conflict that has taken many lives started in 2011, in the flow of "revolutionary" movements across North Africa and some countries of the Middle East. A resolution for applying the Responsibility to Protect (R2P) was not passed by the Security Council of the United Nations due to a veto from Russia and China. The United States was not willing to undertake an intervention on its own. Nevertheless, enormous mistakes were made. President Obama stated in August 2012: '[a] red line for us is we start seeing a whole bunch of chemical weapons moving around or being utilized (...) if we start seeing movement on the chemical weapons front or the use or chemical weapons' (after Tertrais, 2014, p. 9). As Tertrais notes, '[t]he expression "a whole bunch" sounded improvised, and must have left Syrian leaders perplexed.' When it was proved that the Assad regime used chemical weapons, Obama did nothing to back his threats; paradoxically Russia saved America's face with the idea of the destruction of the Syrian arsenal. But that was a stain that could be easily removed from the world's memory. Tertrais notes that there is documented evidence of the influence of the perception of an actor's past behavior on future decision-making. Therefore, others may not treat any declaration of a red line very seriously, like Iran or even Russia did - as in the case of Ukraine, were it is said that 'Obama's "red line" gave 
Putin [a] "green light"'; on the other hand, Taiwan may not want to believe that the U.S. would necessarily protect it from the results of a unilateral declaration of independence (Tertrais, 2014, p. 15). ${ }^{1}$

The disastrous wake of the mendacious stand on Syria led to the rise of ISIS, or the self-named Islamic State of Iraq and the Levant, with the continuous and - in words of Rogers (2015) - disastrous effort to avoid offending (if the truth is offensive) Islamic terrorists. There is a frustrating unwillingness on the president's side to put the words "Islamic" and "terrorist" together. Even better, as Rogers describes, '[m]any were left flat-footed and with jaws dropped' after the president's statement at a National Prayer Breakfast in Washington, where he let the Islamic terrorists know that he was 'keeping their actions in context', and then he felt compelled to equate the Islamic terrorist butchers to the Christian Crusaders from 900 years ago (Rogers, 2015). Granted, the ISIS conflict could not be seen as a regional responsibility for the United States or at least that it is in the best interest of all that troops from the same region fight that war. Nevertheless, as the leading power of the free world, it is U.S. business to at least act more forcefully and assertively on the overall issue of terrorism - because that indeed should be a real American concern.

There is another issue worth mentioning: the tensions between President Obama and Prime Minister Netanyahu. During the recent visit of the latter to the U.S., President Obama decided he was too busy to meet with Netanyahu. And defying the unwritten protocol - maybe just to upset the president - the Speaker of the House invited the Israeli Prime Minister to speak at a joint session of the Congress, an opportunity that Netanyahu could not overlook, particularly now, due to the erratic pseudo-strategy of the executive branch towards Iran. It has been unclear how far the nuclear program of that country will be allowed to expand without becoming a real threat to the region, especially to Israel, as the leaders of that Islamic country have declared repeatedly their desire to wipe Israel from the Earth. Thus Obama's attitude is not very comprehensible. Israel and the United States have always been loyal allies. However, Obama's personality seems to be clashing those of other world leaders, causing mutual antipathy, especially with regard to Vladimir Putin.

1 Tertrais referred to an article presented by Bill Hoffmann about Senator Ron Johnson on Obama's threats and the conflict in Ukraine. 
Russia. The Ukrainian issue poses another problem for the American president. The argument advanced by J. Mearsheimer (2014) in the recent issue of Foreign Affairs clearly states that liberal objectives followed by liberal leaders in the world, namely in the U.S. and the European Union, are not consistent with the real world. It is simple logic. Russia made it very clear that touching its near abroad was not to be tolerated. The result was the annexation of Crimea - which was actually a traditional Russian territory ceded to the Ukrainian Soviet Socialist Republic by then Soviet Premier Nikita Krushchev, himself an Ukrainian. Interfering with Syria may be one thing, and even then, Russia opposed the United Nations Security Council on the issue; but extending the liberal ideals by integrating Ukraine with the European Union and maybe with the North Atlantic Treaty Organization is out of the question. Russia is used to being an empire; even if now its economic capabilities are not performing to their potential, its foreign policy is consistent regardless of the political/economic regime. Moreover, one must not forget that it has indeed the same nuclear capabilities as the United States, which serve as a bargaining tool for deterrence and relative power. And this is a confrontation that has already cost many lives. The German chancellor Angela Merkel is not in favor of providing arms to Ukraine because this certainly may create more problems. The argument of providing "defensive weapons" is in itself an oxymoron. There is no such thing as defensive weapons. Mearsheimer proposes a diplomatic way out, but there are some that think that is not possible as long as Obama insists on showing his usual bullheadedness while remaining clueless as to the Russian reality with respect to their historical need and demand for keeping neighboring states as a buffer against potential threats.

There are also issues and concerns in another part of the world, in a region being contested by what many perceive as a rising power: China. Even if it is very far from being a balancer of power for the region, and far from having America's capabilities, its neighbours do not really like having a country flexing its regional muscles. What does the region say?

Asia-Pacific. President George W. Bush started the Trans-Pacific Partnership (TPP), which reflects the fact that commercial relations have always been a priority for the United States in the region. In 2011, President Obama announced a rebalance for the region, which would involve regional security, economic prosperity and dignity. Nevertheless, security has recently become the most important concern, mainly as the situation in the East and South China Seas has deteriorated. China has been pressuring Japan, Vietnam and the Philippines 
asserting its territorial claims in mercantile and paramilitary terms, while the same is happening in the frozen peaks of the Himalayas with India. And as M. J. Green and Z. Cooper (2014) put it, 'the U.S. response, or lack of one, to chaos in Syria, Iraq, and Ukraine have elicited concern that Washington might either "pivot" away from Asia, or somehow be shown to lack the underlying willpower or resources to manage new security challenges in the Asia-Pacific region' (p. 26). It is evident that the United States has not done enough to demonstrate its commitment to Asia, particularly when other crises are drawing attention to other parts of the world, and none are receiving the focus and attention traditionally expected from the U.S.

Other countries like South Korea are allies of the U.S., but do not want to be in a position to choose between that alliance and China. Countries like Indonesia prefer to support the North American country behind closed doors. And what is China's perception?

China and the U.S. are not necessarily enemies; the world economy is interconnected enough to have both competitors working together. But like Russia, China does not want the superpower around and too close. With respect to Obama's strategy of rebalance in the Asia-Pacific region, China has expressed concern and opposes it as "needlessly destabilizing". On the other hand, the Obama administration has expressed support for President Xi's "New Model of Great Power Relations", which has been seen as an uncomfortable thing for Japan, when China was increasing pressure in the East China Sea. Then, Japan's prime minister Abe was the one asking questions about the U.S. real intentions as to fulfilling commitments to the region, or specifically, of their bilateral treaty (Cooper \& Green, 2014, p. 26).

These few examples may give an inkling of how from the beginning, President Obama has demonstrated a misguided approach to foreign policy and thus they suggest how he might understand America's position in the world. This dates back to the 2008 campaign, when as a senator Obama declared he would agree to meet unconditionally with America's enemies, including the leaders of Venezuela and the other two states labelled rogue, Iran and North Korea. In the opinion of Rogers, this willingness to accommodate America's traditional enemies and to disregard old friends, 'has been a nagging and persistent pattern in the administration from when he was first elected to the present day. (...) [This] just add[s] to the idea that Obama is quick to let America's enemies have their way' (Rogers, 2015).

Finally, the cases are sufficient to explain a pattern. Internationally, both soft and hard activism has waned. Worried about itself, Obama's America has 
become a reluctant power. In world politics, the country has reduced its interests and no longer pursues the specific and unique designs that characterized earlier times. In the American tradition, Roosevelt, Truman and Eisenhower represent a strong containment, along with the establishing of international institutions. Kennedy and Johnson, both Democrats, listened back to Andrew Jackson and Theodore Roosevelt, representing assertive nationalism. Since Wilson through Jimmy Carter to George W. Bush, a course of a global democratic agenda including "regime change" was held. Obama's two terms do not fit any of these traditions, representing neither isolationism nor interventionism, neither exceptionalism nor universalism, neither nationalism nor institutionalism (Joffe, 2013).

Take for example the comments of Chris Hambleton (2014), when he describes the current government:

Over the last four years [2012], we have watched as Barack Obama apologized to lesser, barbarian nations on behalf of America, allowed our embassies to be overrun by terrorists, one of our ambassadors to be slain, strangled our abundant energy supplies, seized control of numerous private industries, businesses, and even our entire healthcare system (...). In only four short years, Obama and the obstructionist Senate - and enabled by the House of Representatives - has added more to the national debt than the first two hundred and fifteen years of our history, more than the first forty-two presidents combined. Under his administration, the Financial Crisis of 2008 turned into the Great Recession which has lasted for more than four years, with the unemployment rates double or even triple what they have been in a generation. The small businesses that haven't closed their doors are barely surviving because of high energy prices, rising taxes, and crushing regulation - with only more of the same on the horizon (pp. 105-6).

A. Etzioni (2004) recalls that several analysts of international relations, like Max Boot, 'argue that it is America's "destiny" to police the world, to impose a Pax America, and to bring democracy to failed states and oppressed people.'

He cites Joshua Muravchik, who maintains that the United States has an imperative to lead the world, just as Robert Wright's study of history leads him to conclude that 'the case for a kind of manifest destiny is stronger than ever.' The concept is a long way from the notion that America's empire was accidental or reluctant, as others have advocated. "To the extent that one takes "destiny" simply to mean that it is the job of the United States, the only superpower, to foster peace worldwide, it does not raise many hackles, although critics would 
prefer for this task to be the work of the United Nations and that it be promoted as much as possible by nonviolent means' (Etzioni, 2004, p. 90).

"Destiny" in the last quote, however, has strong normative, and even religious, undertones. It suggests that the United States has been predestined by something higher to undertake a mission. But being so, the notion that the U.S. has been sent by God to do whatever it chooses implies that it is not accountable to anybody since it has been chosen from all the peoples to bring order to the world. So, the use of the term "destiny" may be an exaggeration but there is an uncontainable truth: the United States and all other powers - as they are endowed with numerous economic assets and military power - have a moral responsibility to help others. Thus the concept of responsibility draws on strong normative roots; it is the basic moral worth of all human beings. The difference between it and the concept of destiny is that responsibility suggests there is no sign that God has chosen the United States to do anything, but that great powers have a responsibility to respect the basic moral worth of all human beings and all that this entails (Etzioni, 2004, p. 91).

Conclusion: American power: its strong institutions and why a bad leader cannot undo its greatness

As Joseph Nye (2015) concedes, a great uncertainty surrounds the question of American institutions. Observers believe that a gridlock in the political system affects the power outcomes of the country. Even if it seems that today the partisan gridlock is worse than in the past, this is not the case. The Congress of the U.S. has seen both cooperation and conflict among the principal political forces. Then what gives continuity to the system is the U.S. Constitution and its institutions.

The Constitution is the highest law that forms the government and its institutions. It was written in a given context and for a unique country. The Delegates of the Constitutional Convention (1787-1788) devised principles that were exacerbated by their ordeal in the difficult war for independence from the British from 1775 to 1781 . These principles included the belief that the United States' citizens and the American family were capable to govern themselves. They saw the purpose of government as a vehicle by which specific rules would be established through a process of representation and indirect democracy. It was the intention of the founders to especially protect individual rights, and they regarded selfgovernment as the ultimate expression of these rights (Morse, 2013).

Being founded on an eighteenth-century liberal view that power is best controlled by fragmentation and checks and balances rather than centralization, the 'American government was designed to be inefficient so that it presented less 
threat to liberty. In foreign policy, the Constitution was written in a way that invites the President and Congress to struggle for control' (Nye, 2015, p. 58). The Constitution established a nation grounded in the principle that power to govern is held by the people. That nation also believes in the principle that all men are free to worship according to the dictates of their conscience, and are equally free; it has thrived on the basis that ideas and hard work open the door to prosperity, regardless of bloodline, skin color or social condition; it is a nation that has remained free because its citizens retain the right to self-defense, property and freedom - the principles that have been enshrined in the founding documents. If destroyed, the foundation is lost and with it, the whole structure collapses under the weight of unbridled tyranny (Hall, 2014).

Then the Constitution established the three branches of government, each with different responsibilities to create a functioning body where power is balanced. The United States are and will remain the largest country in the international system, a country which leads in the global production of goods.

In the words of Stephen Sestanovich on "maximalist" policies and "retrenchment" policies, Nye considers that retrenchment is not isolationism, but an adjustment of goals and means, and in this category, he classifies Eisenhower, Nixon, Ford, Carter, Bush (the first), and Obama (Nye, 2015, p. 118).

As John J. Mearsheimer (2014) asks, what does being a "hegemony" in the modern world mean? It is almost impossible for a state to be a hegemonic leader because it is difficult to maintain power around the world and wield it in the distant territories. The best result that a State could hope for is to be a regional hegemony and dominance in that territory. The United States has been a regional hegemonic leader in the Western Hemisphere since 1900 and is clearly the most powerful state in the world.

It is time to reclaim the concept of realpolitik as the first attempt to answer the riddle that has been at the heart of the Anglo-American foreign policy since forever: how to achieve illustrated liberal goals in a world that does not pursue objectives of enlightened liberals? And how to ensure social and political progress in an unstable and unpredictable environment? This question goes back to the birth of true realpolitik, in an era that has a strong resemblance to the one we live in now. It arose in Europe in the mid-nineteenth century from the clash of the Enlightenment with the realities of power politics: a world undergoing a unique combustion of ideas about freedom and social order, along with rapid industrialization, class war, sectarianism, great power rivalry and the emergence of nationalism. It was the answer to the dilemmas of modernity par excellence, some of which Americans are still grappling with today (Bew, 2014). 
[Then a] seemingly unrelated point is very much at issue here: The costs of a new global architecture. Many have questioned whether the United States is willing to shoulder the costs of running the empire it has formed. These costs, however, are not set in stone; they greatly depend on what ordering the world entails. Enhancing safety, removing tyrants, and opening a country incurs substantial costs, but they pale in comparison to what democratization and development or "reconstruction" require (Etzioni, 2004, p. 80).

The United States is the world leader and is likely to remain so for decades. It has been the largest soft power in the world so far; it receives many more immigrants each year than any other country in the world (1 million); it is a world leader in high technology (Silicon Valley), finance and business (Wall Street), film (Hollywood) and higher education (17 of the top 20 universities in the world according to a study of Jaotong University in Shanghai); and it has a first-world business profile (massive exports of consumer goods and technology and imports of natural resources). It is still the world leader in foreign direct investment (FDI) with $\$ 180$ million, almost double of its nearest competitor; with an expenditure of $\$ 560$ billion dollars a year, it has the most powerful army in the world. Its GDP ( $\$ 16$ billion) is more than twice that of China. The U.S. functions as one of the world's leading democracies. Its market still reflects American leadership in the global economy (Adelman, 2013). The United States will overcome the difficulties despite their leaders, given its foundations and the original construction of its institutions.

In the spirit of Winston Churchill, 'you can count on Americans always will [sic!] do the right thing... after they have exhausted all other possibilities' (cited in Ashgar, 2013).

\section{REFERENCES}

Adelman, J. (2013). Why The U.S. Remains The World's Unchallenged Superpower. Forbes. Retrieved on May 20, 2014 from https:/www.forbes.com/sites/realspin/2013/11/24/ why-the-u-s-remains-the-worlds-unchallenged-superpower/\#691396b55b6e

Albright, M. K. (2003). United Nations. Foreign Policy 138, 16-18, 20, $22,24$.

Asghar, R. (2013). The Myth of America's Decline: Why the U.S. Won't Lose the Globalization Game [Kindle edition]. Retrieved from www.amazon.com

Bew, J. (2014). The Real Origins of Realpolitik. The National Interest 130 [Kindle edition]. Retrieved from www.amazon.com

Cliffnotes. (2014). The United States as a World Power. Houghon Mifflin Harcourt. Retrieved on April 7, 2015 from http://goo.gl/X8sKxB 
Etzioni, A. (2004). From empire to community. A new approach to international relations. New York: Palgrave Macmillan.

Folsom Jr., B. \& Folsom, A. (2010, April 12). Did FDR End the Depression? The Wall Street Journal. Retrieved on April 13, 2015 from http://goo.gl/IaZc6P

Friedman, G. (2013). Beyond the Post-Cold War World. Stratfor. Retrieved on April 12, 2015 from http://goo.gl/uhgW0G

Green, M.J. \& and Cooper, Z. (2014). Revitalizing the Rebalance: How to Keep U.S. Focus on Asia, The Washington Quarterly 37(3), 25-46.

Hall, K. (2014). Sovereign Duty [Kindle edition]. CreateSpace Independent Publishing Platform. Retrieved from www.amazon.com

Hambleton, C. (2014). Who are Americans? (Our American Awakening Book 2) [Kindle edition]. Retrieved from www.amazon.com

Hirsh, M. (2004). Cited in A. Etzioni, From empire to community. A new approach to international relations. New York: Palgrave Macmillan.

Lind, M. (2014, July 12). The American Century is over: How our country went down in a blaze of shame. Salon. Retrieved on 13 April 2015 from https:/www.salon. com/2014/07/12/the_american_century_is_over_how_our_country_went_down_ in_a_blaze_of_shame/

Joffe, J. (2013). The Myth of America's Decline: Politics, Economics, and a Half Century of False Prophecies [Kindle edition]. Liveright. Retrieved from www.amazoncom

Lizza, R. (2011, April 26). Leading from behind. The New Yorker. Retrieved on Aprl 11, 2015 from http://goo.gl/wl5tkA

Mearsheimer, J. (2014). Why the Ukraine Crisis Is the West's Fault. The Liberal Delusions That Provoked Putin. Foreign Affairs 93 (5), 1-12.

Mearsheimer, J. J. (2013). Taiwan's Dire Straits The National Interest 130, pp. 29-39.,

Morse, C. (2013). American Testament - The Declaration of Independence and the U.S. Constitution: keys to America's future [Kindle edition]. City Metro Enterprises. Retrieved from www.amazon.com

Newell, J. (2014). U.S. Foreign Policy Study Guide: An In-Depth Analysis of U.S. Foreign Policy, [Kindle edition]. Athena LLC. Retrieved from www.amazon.com

Nye, Jr, J.S. (2015). Is the American Century Over?[Kindle edition]. Polity. Retrieved from www.amazon.com

Rogers, E. (2015, February 23). The Insiders: Why would anyone think Obama doesn't love America? Plenty of reasons. The Washington Post. Retrieved on February 23, 2015 from http://www.wapo.st/1zaPuE9

Tertrais, B. (2014). Drawing Red Lines Right. The Washington Quarterly 37(3), 7-24.

US Department of State. (n.d.). A Short History of the Department of State, Retrieved on April 7, 2015 from http://goo.gl/9yH5on

Waltz, K. (2000). Structural Realism after the Cold War. International Security 25(1), $5-41$.

The White House. (2015). The Executive Branch. Retrieved on January 18, 2015 from http://goo.gl/aJTvV 